\title{
The Impacts of Settlement Extension on Soil Resources: A Case Study in Drenica River Basin (Kosovo)
}

\author{
Valbon BYTYQI \\ Received: 30042018 / Accepted: 28062018 / Available online: 30062018 \\ (C) 2018 Fakultas Hukum dan IImu Sosial UNDIKSHA dan IGI
}

\begin{abstract}
Rapid extension of settlements in Kosovo has made major changes in land use and land cover. Migration of population towards plains has reduced the number of inhabitants in hillymountainous areas where low fertile soils are found. Significant part of agricultural land are changed from primary destination, and agricultural potentials are reduced. Urbanization in many cases is made in unplanned way, and in our study area in Drenica River basin are observed land degradation forms and other environmental transformations where in some cases the risk of flooding increased and floods appeared. This study about Drenica River basin will discuss aspects of the influence of morphology, water flows, and the land capability in the distribution of population, and will be a contribution to sustainable urbanization of settlements and agricultural land preservation. In order to accomplish the research are used satellite images, maps of different years, and the census data for the purpose of better coverage that has influence in the process of urbanization on soil resources in Drenica River basin (Kosovo).
\end{abstract}

Key words: Land Use; Degradation; Urbanization; Drenica River Basin; Kosovo

\section{Introduction}

Humans live close to and depend on the soil. It is one of the thinnest and most vulnerable human resources and is one upon which, both deliberately and inadvertently, humans have had major impacts (Richter, 2007).

Agricultural lands in the periphery of the cities serve as transition zones from natural and rural habitats to urban landscapes. They serve as a supplier of vital ecosystem services such as food, feed, clean air, soil and water to the urban areas and as buffer zones to diminish negative effects of the urban systems on the natural environment (Doygun, 2009).

Expansion of urban, suburban, and exurban development into agricultural landscapes and other rural settings has prompted much public concern over land use. Alarming estimates of the loss of farmland have been suggested, as have startling visions of extensive idling of

Valbon BYTYQI

Department of Geography, FMNS, University of Prishtina, Kosovo

valbon.bytyqi@uni-pr.edu farmland in anticipation of future urban development or because of intolerable spillover effects from nearby urban development. To sustain this concern over declining agriculture in urban regions of the country, there appears to be an association between increases in population and losses of farmland (BERRY, 1978). The growth and urbanization of the global human population over the last 50 years has resulted in the rapid increase in total share of global population on the one hand, and the unprecedented spatial expansion of a number of cities, on the other. While the world's megacities (i.e., those estimated to contain more than 10 million inhabitants) offer striking examples of the environmental challenges that accompany urbanization, environmental degradation has not been avoided by cities of any size (Hardoy, Mitlin, Satterthwaite, \& Hardy, 2001). The rapid and random expansion of urban centers has caused changes on land cover. Forests and water catchment areas are faced with the threat of a dense settlement (Archer, 1989), (Mount, 1995). 
Agricultural capacity is reduced due to urban sprawl on high quality agricultural land (Kim, Kobayashi, \& Mizuno, 2003). Indeed, the impact of urban activities of cities of all sized on local, regional, and global scale environmental trends is increasing (Millennium Ecosystem Assessment, 2005). The growth of the number of population is affected in Kosovo settlements, and also the extension of settlements. Thus, most of the settlements are concentrated in plain areas, the effects of urbanization had more impact on most fertile soils of Drenica River basin. Soils have received an increased attention. The impact of urbanization on agricultural land became an academic concern during the 1950s (Bogue, 1956). By the late 1960s, Gilbert was able to put together a comprehensive study of the impact of cities on various environmental resources, and included an entire chapter on soils. (Gilbert, 1989). During the 1990s, the literature on urbanization and its impact on soils expanded significantly. The direct effects of urbanization and population decentralization involve, of course, the conversion of land from rural to urban uses (BERRY, 1978).

Two important reasons why cities are becoming driving forces in environmental trends in the increasing share of the global population that resides in urban areas and the increased intensity of activities that these populations bring to cities (Marcotullio, Braimoh, \& Onishi, 2008). The world recently hit a level of $50 \%$ urbanization and the United Nations (United Nations, 2001) predicts that the share of urban population will increase to $60 \%$ over the next 30 years.

Land use plans in the Drenica River basin, and in general throughout Kosovo are not fully implemented, so as a result of non-implementation, agricultural lands has changed the primary destination, and becoming construction sites. Destination change of soils has influenced the development of other processes, such reduction of soil resources, erosion, local climate, etc. Number of population and settlements in the hilly and mountainous areas is declining. Precisely, these inhabitants are migrating toward plains with high fertile soils. In this case, the number of inhabitants in plain settlements increased, whereas the existing settlements are extended. In the past, the periphery of settlements (cities and villages) have been transition space between the urban landscape and natural habitats while today, periphery of settlements is being extended at a rapid pace into construction space. Thus, urbanization has led to changes in land cover. Improper planning has affected large agricultural lands, especially near the main roads of the basin.

\section{Study area}

Kosovo lies in southeastern part of Europe. It is a landlocked country, bordered with Albanian in southwest, FYR of Macedonia in south, Montenegro in west, and Serbia in north and east. Total area of the country is 10,905 square kilometers. Country's landforms are divided in two types: mountains of small and medium altitude, and plains between them. About $63 \%$ of country's area is in altitude above 700 meters, and only $37 \%$ of the area lies below 700 meters altitude. The main agricultural fields in Kosovo are: Dukagjini basin, Kosova basin, Llapi basin, Anamorava basin and Drenica basin. 


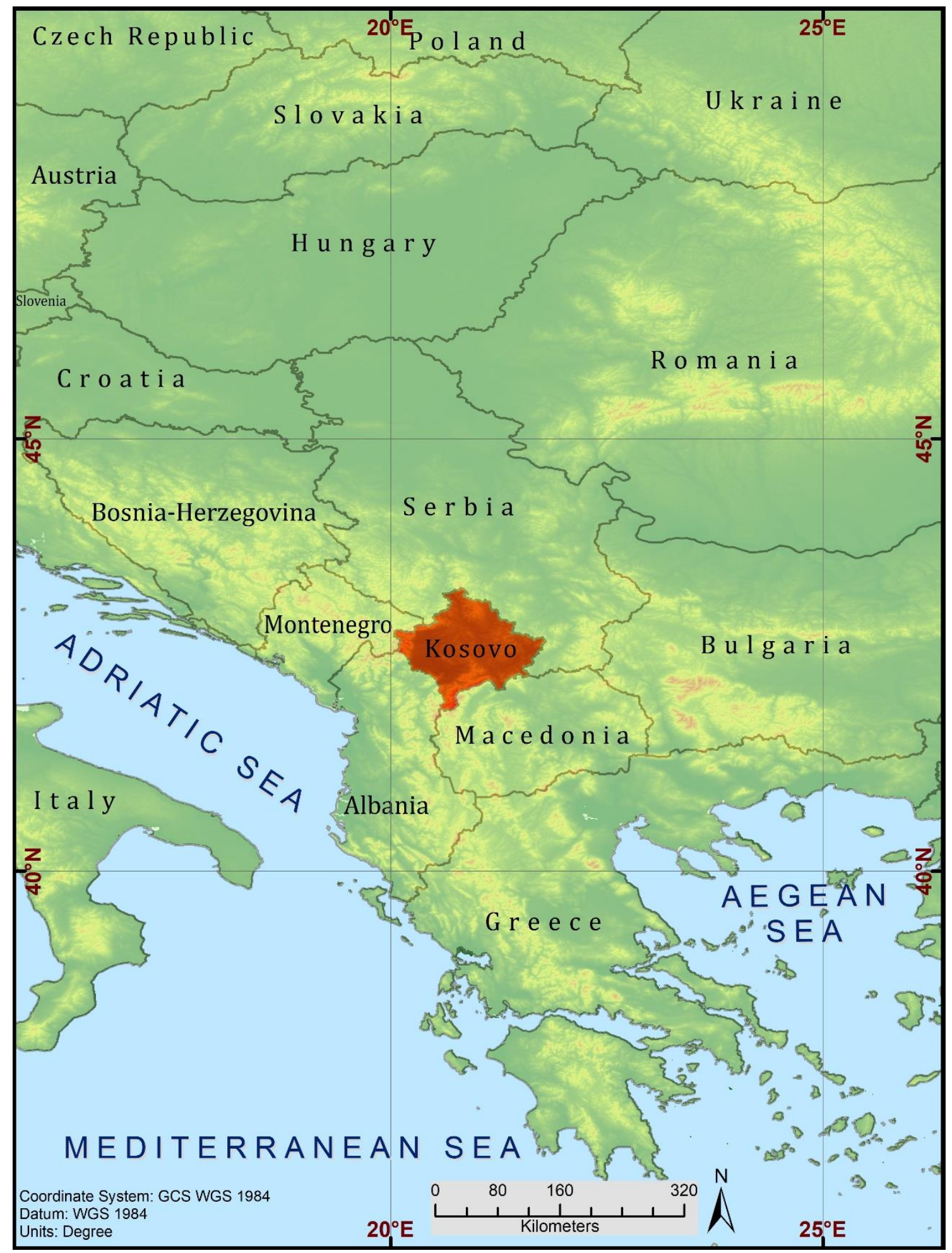

Fig. 1. Geographical position of Kosovo in Europe

Drenica River basin is situated in center part of Kosovo (Fig. 2). The basin's area is $439.4 \mathrm{~km}^{2}$ and comprises $4.03 \%$ of total area of Kosovo. The basin has good geographical location, enabling the connection of the central part of the Balkan Peninsula with Kosovo, where streets then continue towards the Adriatic Sea. 


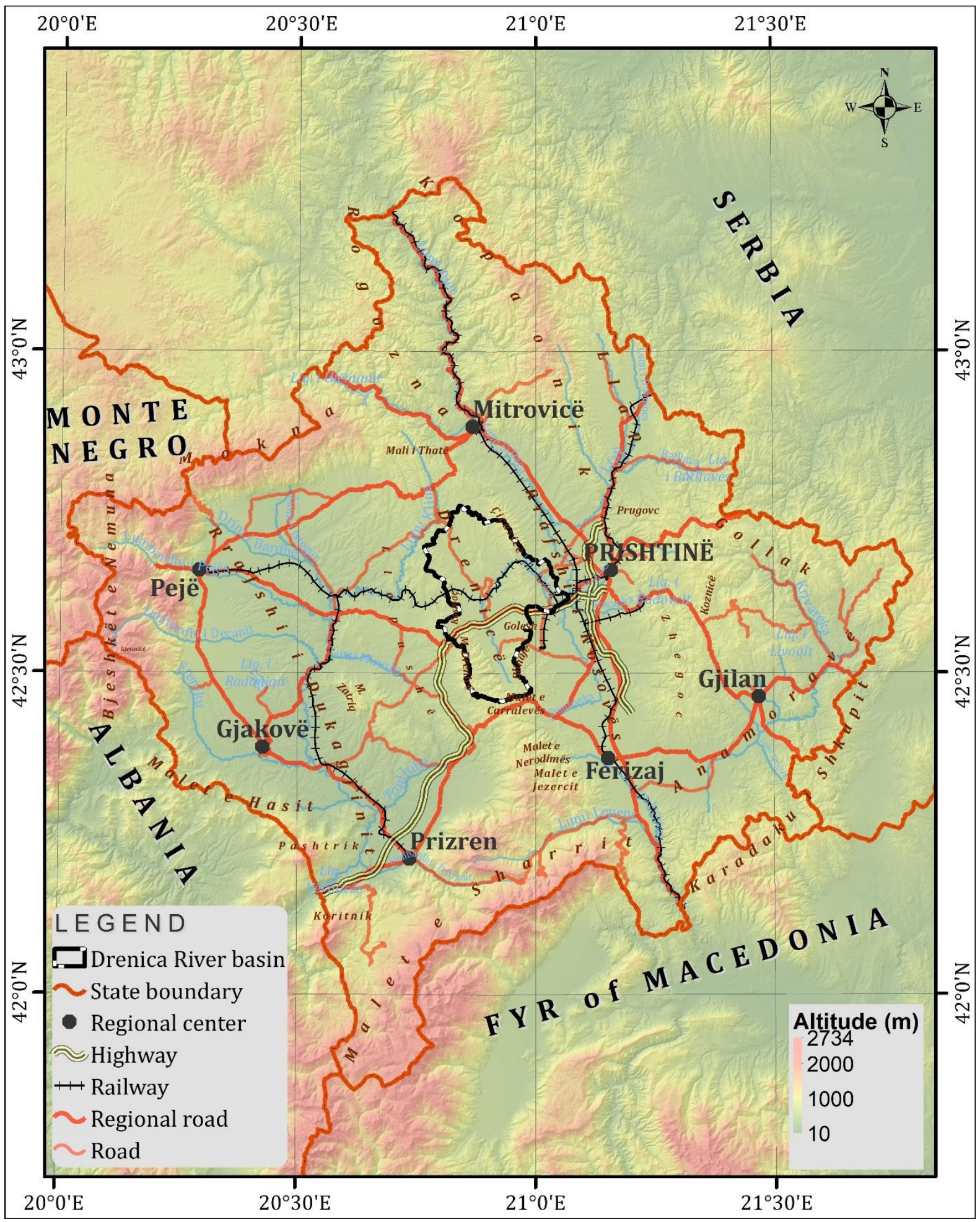

Fig. 2. Location map of study area in Kosovo

Drenica River basin is characterized by diverse geotectonic condition represented by magmatic, sedimentary and metamorphic rocks. At southeastern part of the River basin are found metamorphic rocks (phylite, sericitic and quartzite schists with some marbles). In eastern part are found ultrabasic rocks (peridotites). The western edge is consisting of sedimentary rocks, mainly 
calcareous flysch. The lowest part of Basin is consisting of young sedimentary rocks (sand, gravel, clay). Alluvium is found in alluvial plain of Drenica River.

The basin is characterized by diversified morphological conditions. The lowest point in the basin is 442 meters above sea level (Drenica River mouth), while the highest point is 1,089 meters (Golesh). Most of the basin lies at altitudes up to 700 meters $(66.5 \%)$. This part of the Drenica River basin is characterized by plain relief, smooth slope morphology and, as a result of high fertile soils. The areas

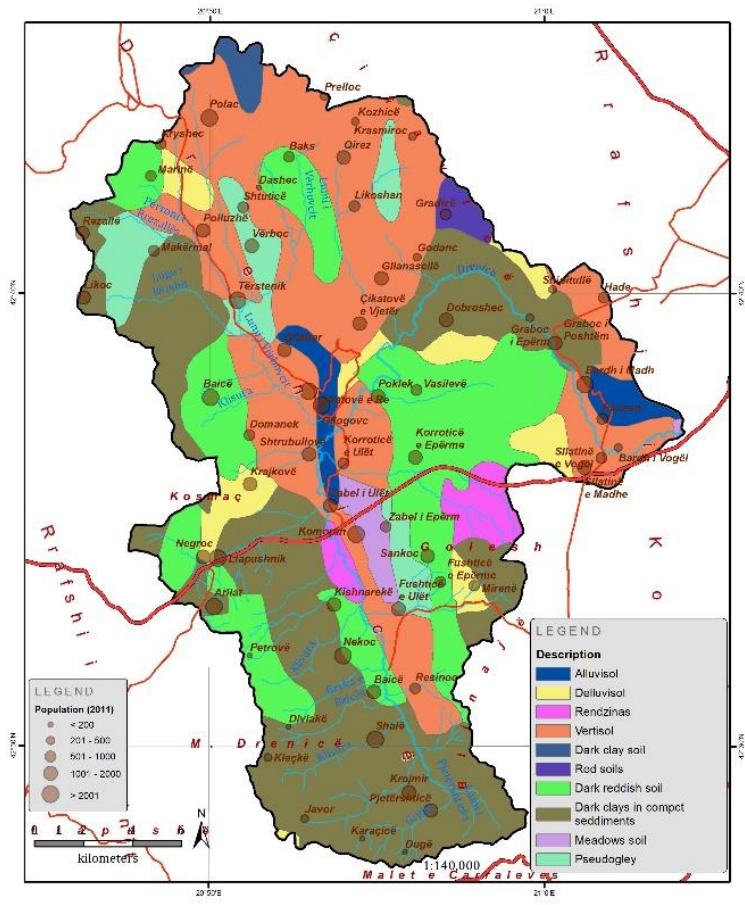

Fig. 3. Soil types in Drenica River basin

The basin population have played an important role on soil resources (Fig. 3 and 4). As a result of the geographical conditions, in the basin dominant soils are brown soils in compact layers (62.2\%) located in the northern and southern parts of the basin, at an altitude of over 800 meters and associated mainly with compact rocks. Alluvisols occupy $10.3 \%$ of surfaces and stretching along the main above 700 meters above sea level are located mainly in the east, southeast and west part of the basin. The basin is characterized by a continental climate with isotherm of $10-11^{\circ} \mathrm{C}$, in hilly and mountainous areas average annual temperatures vary between $10^{\circ} \mathrm{C}$ and $7^{\circ} \mathrm{C}$. Average annual rainfall are $600 \mathrm{~mm}$. According to the Köppen climate classification, Drenica River basin belongs to type C. The main river is Drenica River which flows toward the Sitnica River (Black Sea) (Bytyqi, 2017).

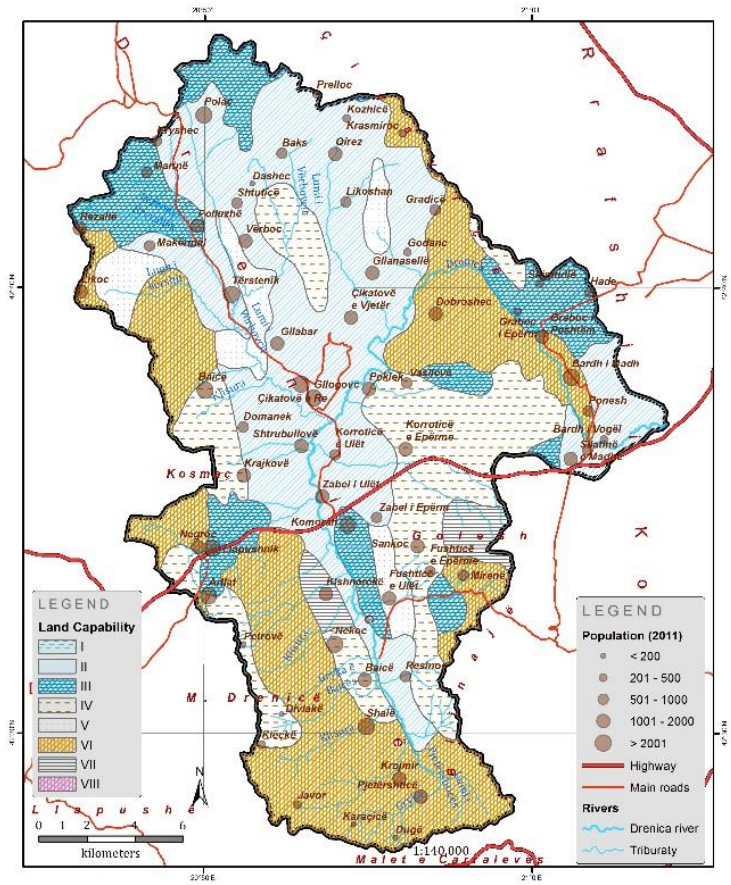

Fig. 4. Land capability classification in Drenica River basin

river and some of the larger tributaries. While the rest of the basin (27.5\%) is covered by soils as deluvium, vertisols brown reddish, pseudogley, rendzinas (Table 1). 
Table 1. Type of soils in Drenica River Basin

\begin{tabular}{|c|c|c|}
\hline Description & Area (hectares) & $\%$ \\
\hline Alluvial soils & $1,067.6$ & $2.43 \%$ \\
\hline Diluvium soils & $2,136.5$ & $4.86 \%$ \\
\hline Vertisol & $13,145.2$ & $29.91 \%$ \\
\hline Dark clay soils & 359.0 & $0.82 \%$ \\
\hline Dark reddish soils & $9,183.6$ & $20.90 \%$ \\
\hline Pseudogley & $2,380.8$ & $5.42 \%$ \\
\hline Rendzina & $1,077.6$ & $2.45 \%$ \\
\hline Dark soil in compact rocks & $13,634.5$ & $31.03 \%$ \\
\hline Meadow soil & 609.5 & $1.39 \%$ \\
\hline Terra rosa & 350.3 & $0.80 \%$ \\
\hline & $43,944.5$ & $100.00 \%$ \\
\hline
\end{tabular}

(Source: Soils map of Kosova)

Heterogeneous space of Kosovo, with great natural resources and strategic position in the Balkan Peninsula was more attractive to the population, so from the greed of many different peoples, Kosovo as the whole region was the scene of conflict, by changing rulers and regimes one after another, while the native population experienced the raging waves of the long history in the past 2000 years (Islami, 1985). Population of this area dates very early from the Paleolithic period. Other settlements belonging to the Illyrian tribes of Dardans. During this period, settlements were built on the highest peak and had strategic position (Ramadani, 2004). In the census of 1948 after World War II, in the settlements of
Drenica River basin were registered 27, 228 inhabitants. Over the years, the population increased through natural growth rate and internal migrations (Fig. 5). Thus, based on census (Kosovo Census Data 2011, 2011), in the Drenica River basin are living 83,328 inhabitants in 65 settlements ( 2 urban and 63 rural). The average population density is different according to altitude. With higher density are areas below 700 meters above sea level, where the density is 249 inhabitants $/ \mathrm{km}^{2}$. Mountainous and hilly areas have lower density around 26 inhabitants $/ \mathrm{km}^{2}$. Average population density is $190 \mathrm{ihb} . / \mathrm{km}^{2}$, the same as the country (Kosovo).

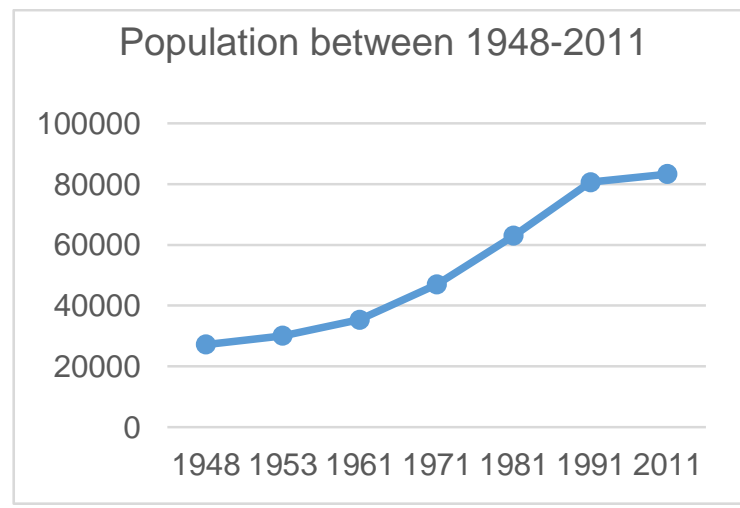

Fig. 5. Population growth in Drenica River basin 1948-2911 (Kosovo Census data) 
3. Materials and methods

In order to achieve the goals of this work, different methods were used. The number of population and different demographic tendencies was analyzed with geostatistical methods. In this article, different maps (morphological, climate, soils, etc.) that show the morphology of terrain, soil types, slopes in Drenica River basin, are presented. Population statistics are used from census of 2011 (Kosovo Census Data 2011, 2011). Aerial images of different years were used as case studies for the problem. All of these features were analyzed with ArcMap 10.1 software, and presented with thematic maps. At the end, a comparison between in timeline was made to show the tendencies in extension of settlements and their impact in reducing soil resources in Drenica River basin.

\section{Results and discussion}

The limit of land use and crops production is conditioned not only by latitude but also by altitude, terrain morphology, climate, etc., and relief aspect (Ramadani et al., 2011). The morphology of the terrain plays An important role in the creation of soil resources and other qualitative features of soil fertility. Based on the criterion of slope (Bognar, 1991), soils are divided into 5 categories (Table 2). Thus, from total area of 43,944 hectares of the basin, lands suitable for agriculture are 18,515 hectares $(42.1 \%)$. Slopes relatively suitable for agriculture with the existence of risk from erosion are 15,351 hectares (34.9\%). These two categories of slopes make up $77 \%$ of the total area of the basin. These categories are located mainly in the plains, at an altitude below 700 meters, in floodplains, and where most of settlements are located (Fig. 6).

Restrictive category of slopes for the most important agricultural use $\left(12-25^{\circ}\right)$ are 8,997 hectares $(20.5 \%)$, while the rest are slopes useful for agriculture through terracing or only for forestry $(2.5 \%)$.

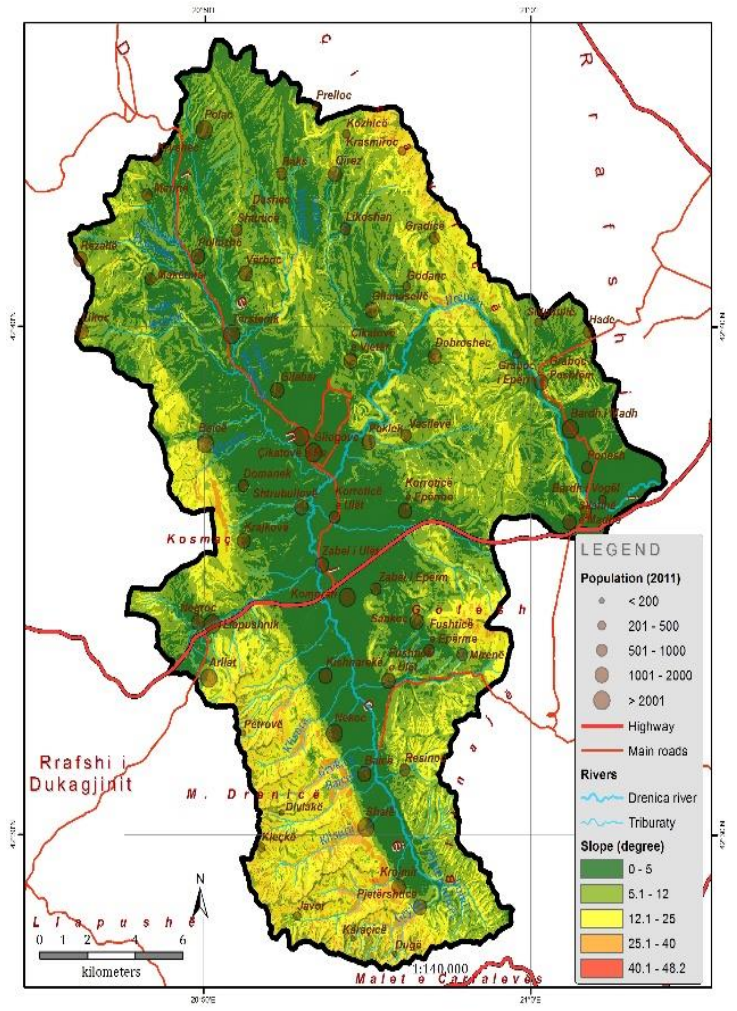

Fig. 6. Slope of topography in Drenica River basin

Table 2. Slope categories and their area in Drenica River basin

\begin{tabular}{|c|c|c|c|}
\hline Slope & Category of slope & Area (ha) & $\%$ \\
\hline$<5^{\circ}$ & Slopes suitable for agriculture & $18,515.12$ & 42.1 \\
\hline $5-12^{\circ}$ & $\begin{array}{l}\text { Slopes relatively suitable for agriculture with the existence } \\
\text { of risk from erosion }\end{array}$ & $15,351.80$ & 34.9 \\
\hline $12-25^{\circ}$ & $\begin{array}{l}\text { Restrictive category of slopes for the most important } \\
\text { agricultural use }\end{array}$ & $8,997.16$ & 20.5 \\
\hline $25-40^{\circ}$ & Slopes useful for agriculture through terrace & $1,077.52$ & 2.5 \\
\hline \multirow[t]{2}{*}{$>40^{\circ}$} & Slopes useful only for forestry & 2.92 & 0.0 \\
\hline & Sum: & $43,944.52$ & 100.0 \\
\hline
\end{tabular}


Also, based on the general conditions of soils creation, an important role plays land capability (fertility of soils), which is a prerequisite for the development of agriculture. Thus, based on land capability, soils in Kosovo are divided into 8 categories, where the categories of I-IV are considered as agricultural land (Law no. 02/L-26), and as written in a law, construction is not allowed on these lands. Based on the information obtained from maps, in Drenica River basin, agricultural land (class I-IV) are in total 28,308 hectares or $64.4 \%$. If we put in relation to the number of population with agricultural lands (class I-IV), it appears that for every inhabitant belongs 0.34 hectares of class I-IV, an amount lower than the European average. Characteristic of these soils are suitable physical conditions, smooth slope, an easy way to irrigate them, etc. The rest of the lands belongs to the category $\mathrm{V}-\mathrm{VII}$ which are considered as land not suitable for agriculture, which can be used for meadows, pastures, forests, and for wild world. Based on the maps, land of categories V-VII are 15,636 hectares that means for every inhabitant belongs 1.87 hectares of soils type V-VII (however, these lands are not considered arable land) (Table 3). From the results obtained, lands capability in Drenica River basin are noted in a small presence agricultural land, which could be a limiting factor in the development of agriculture. Also, seeing the trends of settlements urbanization, it can be concluded that in the future, the area of agricultural land per capita will be under the standards for stable supply of the population with agricultural products.

Table 3. Land capability classification for Drenica River basin

\begin{tabular}{clcr}
\hline Class & \multicolumn{1}{c}{ Land Capability Classification } & Area (hectares) & $\%$ \\
\hline II & $\begin{array}{l}\text { Have some limitations that reduce the choice of plants } \\
\text { and require moderate conservation practices }\end{array}$ & $14,944.64$ & $\begin{array}{r}34.01 \\
\%\end{array}$ \\
\hline \multirow{2}{*}{ III } & $\begin{array}{l}\text { Same as II but require special and intense } \\
\text { conservation practices }\end{array}$ & $5,281.08$ & $\begin{array}{r}12.02 \\
\%\end{array}$ \\
\hline IV & $\begin{array}{l}\text { Very severe limitations that restrict plant choice and } \\
\text { require careful management }\end{array}$ & $8,082.32$ & $\begin{array}{r}18.39 \\
\%\end{array}$ \\
\hline \multirow{2}{*}{ V } & $\begin{array}{l}\text { Cannot be tilled, therefore it is used for pasture, timber } \\
\text { or wildlife. }\end{array}$ & $2,207.05$ & $5.02 \%$ \\
\hline VI & Same as V & $12,441.50$ & $\begin{array}{r}28.31 \\
\%\end{array}$ \\
\hline VII & Woodland and wildlife use & 987.92 & $2.25 \%$ \\
\hline & Sum: & $\mathbf{4 3 , 9 4 4 . 5 0}$ & $\mathbf{1 0 0 \%}$ \\
\hline
\end{tabular}

(Source: Land capability map of Kosovo)

The area of Drenica River basin is populated quite early. The first settlements were located in hilly terrains that had strategic defense position. Based on the census of 2011, in River basin are living 83,328 inhabitants, distributed in 65 settlements. Numerical size of the settlements is associated with elevation of the basin. Thus, while the territories below 700 meters sea level occupied $66.5 \%$ of the area, there are living $87.2 \%$ of the population (72,701 inhabitants), inhabited over 49 settlements. Also, the population density is associated with altitude. Thus, greater density of population is at an altitude of up to 700 meters, where the density is 249 inhabitants $/ \mathrm{km}^{2}$, whereas in areas between 700 to 900 meters altitude, density is 82 inhabitants $/ \mathrm{km}^{2}$, while areas above 900 meters population density is 26 inhabitants $/ \mathrm{km}^{2}$. (Table 4). 
Table 4. Demographic characteristics of Drenica River basin

\begin{tabular}{lrrrrrr}
\hline $\begin{array}{l}\text { Altitude } \\
(\mathbf{m})\end{array}$ & $\begin{array}{l}\text { Area } \\
\left(\mathbf{k m}^{2}\right)\end{array}$ & \% of area & $\begin{array}{l}\text { Number of } \\
\text { settlement }\end{array}$ & $\begin{array}{l}\text { Population } \\
(\mathbf{2 0 1 1})\end{array}$ & $\begin{array}{l}\text { \% of } \\
\text { population }\end{array}$ & $\begin{array}{r}\text { Density } \\
\mathbf{( 2 0 1 1 )} \\
\left(\mathbf{i n h} . \mathbf{k m}^{2}\right)\end{array}$ \\
\hline$<700$ & 292.1 & $66.5 \%$ & 49 & 72,701 & $87.2 \%$ & 249 \\
\hline $701-900$ & 122.3 & $27.8 \%$ & 10 & 9,973 & $12.0 \%$ & 82 \\
\hline$>900$ & 25.1 & $5.7 \%$ & 6 & 654 & $0.8 \%$ & 26 \\
\hline & $\mathbf{4 3 9 . 4}$ & $\mathbf{1 0 0 . 0 \%}$ & $\mathbf{6 5}$ & $\mathbf{8 3 , 3 2 8}$ & $\mathbf{1 0 0 . 0 \%}$ & $\mathbf{1 9 0}$ \\
\hline
\end{tabular}

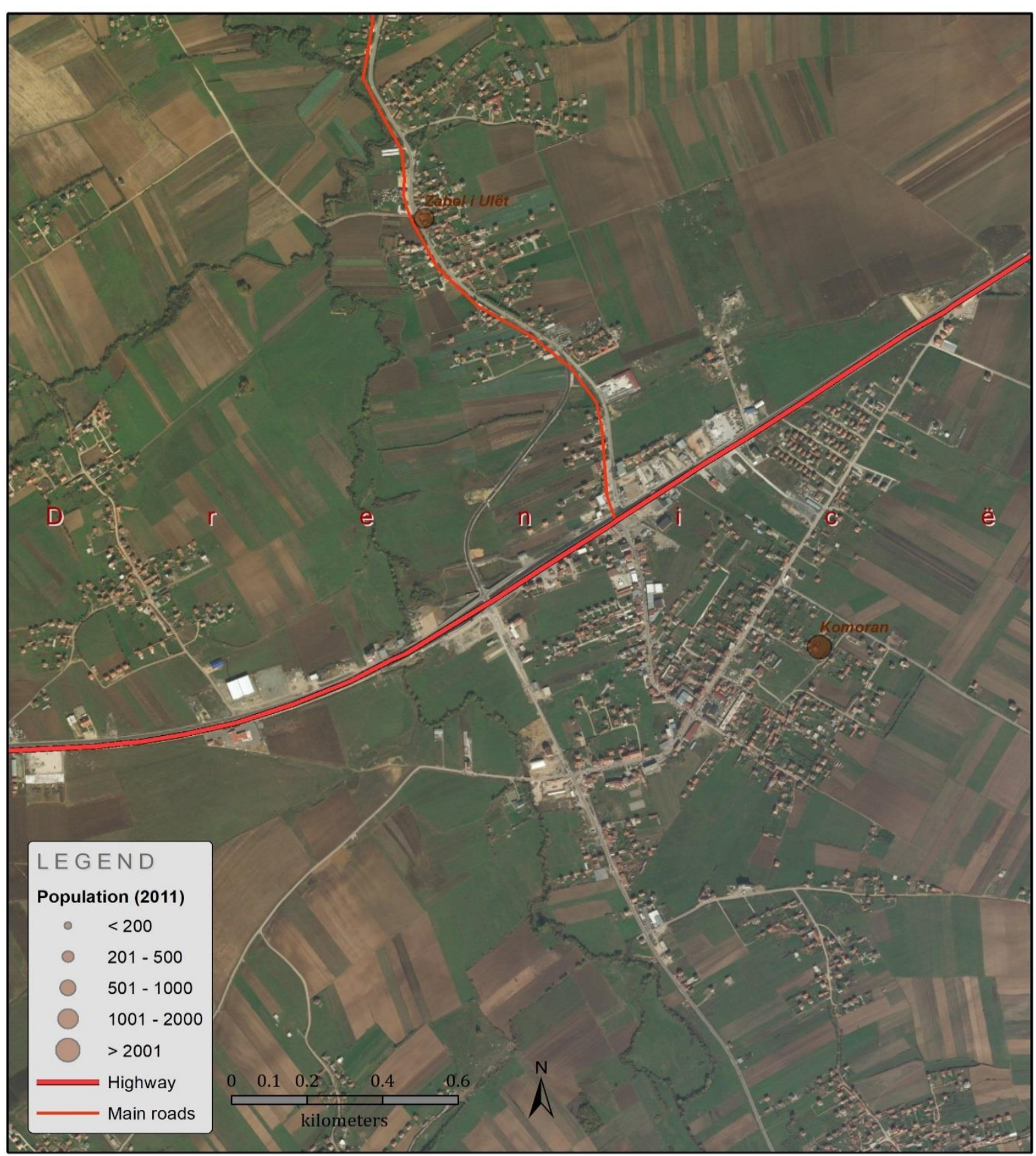

Fig. 7. Example of settlements extended in agriculture land and near main roads 
Density of settlements requires the extension of infrastructure. Most of the settlements which also have large numbers of inhabitants are located up at an altitude of 700 meters. In this area are 16.7 settlements in every $100 \mathrm{~km}^{2}$. While, at altitude between 700-900 meters are 8.1 settlements in every $100 \mathrm{~km}^{2}$. However, the biggest differences are observed in the numerical size of settlements in different altitude zones (Fig. 8).

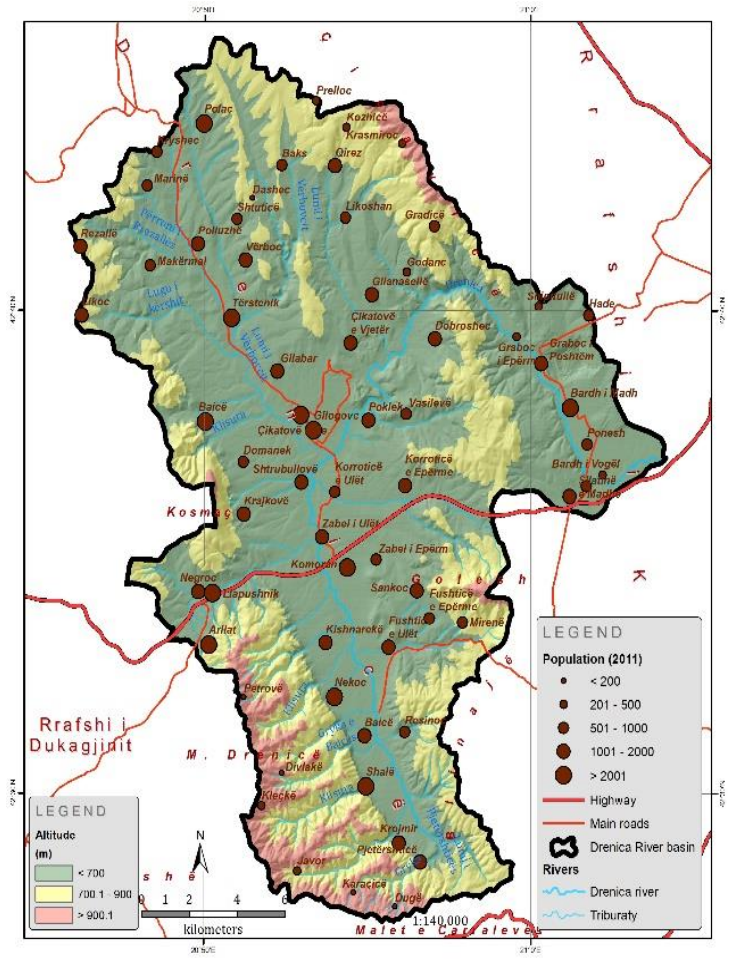

Fig. 8. Concentration of settlements in Drenica River basin
The population density, the number and type of settlements are factors that affect the urbanization on Drenica River basin. Therefore, the greatest concentration of population in the plains has shown the largest effects of urbanization on soil resources. Based on these facts, the number and density of the population through urbanization have contributed to the development of other processes, such as erosion, local climate, floods, etc.

With the extension of settlements and the construction of supporting infrastructure, soil resources are reduced. Currently, most of the infrastructure is concentrated in agricultural lands with high fertile soils (Fig. 7 and 9), smooth slope which is up to 700 meters above sea level. From total area of Drenica River basin from 43,944 hectares, about $9.5 \%(4,158$ hectares) is covered by the physical infrastructure built by human activities. Most of these construction sites are residential facilities that occupy $8.46 \%$ of basin's total area. The rest includes: roads, industrial facilities, military, etc. Today, the problem of the construction of individual houses, which in this case are making the fragmentation of agricultural plots, can be seen overall due to unplanned way of settlements. Actually, from all construction sites in the area of the basin, the process of urbanization has affected about $9.46 \%$ of it. (Table 5, Fig. 9)

Table 5. Area covered by human activities

\begin{tabular}{|c|c|c|c|c|}
\hline & \multicolumn{4}{|c|}{ Area covered (hectares) } \\
\hline Land use & 2012 & $\%$ & 1990 & $\%$ \\
\hline Cemetery & 2.66 & 0.01 & & \\
\hline Industrial area (coal mines, facilities) & 136.40 & 0.31 & 146.56 & 0.33 \\
\hline Settlements & $3,717.42$ & 8.46 & 772.23 & 1.76 \\
\hline Others (roads, cemetery, landfills, etc.) & 302.13 & 0.69 & 150.25 & 0.34 \\
\hline Total area: & $4,158.61$ & 9.46 & $1,069.05$ & 2.43 \\
\hline
\end{tabular}




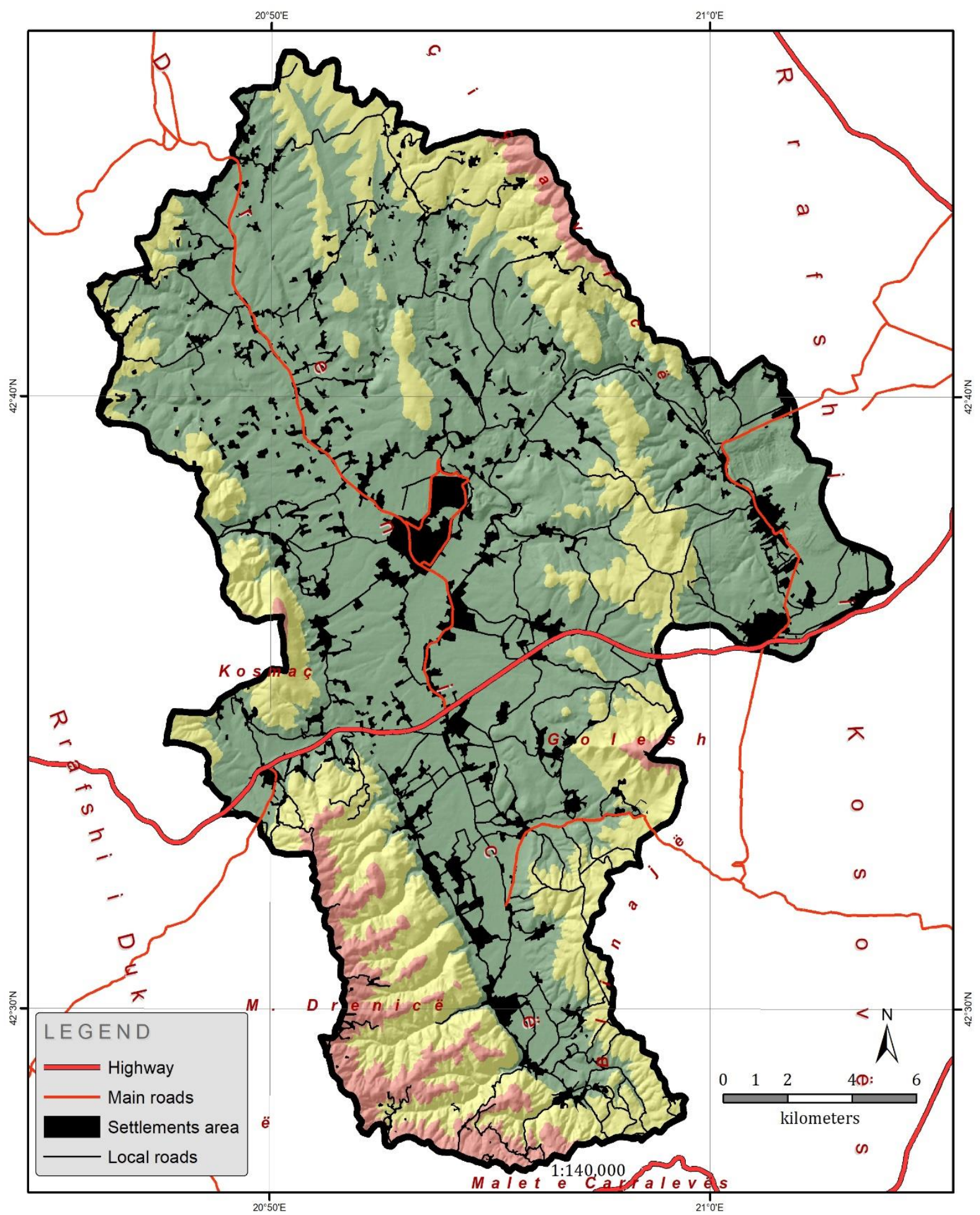

Fig. 9. Area covered by settlements and infrastructure in Drenica River basin

\section{Conclusions}

The lowest part of Drenica River basin (Kosovo) is known for its high fertile soils. It is also knows as one of the main areas of agricultural development in center part of Kosovo and more. Based on the data obtained during the research, show that in the Drenica River basin, agricultural land 
(class I- IV) are in total 28,308 hectares or $64.4 \%$. So, $2 / 3$ of the area is characterized by adequate relief and smooth slope. Drenica River basin is characterized by high population density, especially in the plains that comes as a result of suitable physical and geographical conditions.

As a result of the urbanization process, land cover in the Drenica River basin changed. Changes in land use are more evident as a result of nonimplementation of municipal and urban development plans. Field observations noted large concentration of settlements in plains up to 700 meters above sea level, where most of the settlements and the population are located. Also, the extension of rural settlements is done in an unplanned manner with reducing the soil resources and fragmenting agricultural areas. Extension of settlements is mainly done along the main roads to gain access directly.

As a result of the urbanization, negative phenomenon are observed dealing with the impact of urbanization on agricultural lands with high fertile soils: permanent loss of agricultural land due to settlement extension, development of commercial activities and building the necessary infrastructure (especially along the roads). Erosion processes are more frequent, and floods due to morphological changes occur more easily in floodplains. In April 2014, several villages were flooded, which was the result of intense rainfall but also the spatial defiance.

In order to protect and use of soil resources in a sustainable manner, the process of urbanization should consider the small fund of soil resources in Drenica River basin and all around Kosovo. This small fund of soil resources with limited resources per capita is the basis for the development of future agriculture in Kosovo.

\section{References}

Archer, D. R. (1989). Flood wave attenuation due to channel and floodplain storage and effects on flood frequency in floods. In Editor John Wiley (Ed.), Hydrological, sedimentological and geomorphological implication (pp. 37-46). New York: John Wiley.

BERRY, D. (1978). Effects of Urbanization on Agricultural Activities. Growth and Change.

https://doi.org/10.1111/j.14682257.1978.tb01024.x

Bognar, A. (1991). GeomorphologicalEngineering cartography. In Geographical Research 13 (pp. 333339).

Bogue, D. . (1956). Metropolitan growth and the conversion of land to nonagricultural uses. In Studies in population distribution. Ohio: Oxford.

Bytyqi, V. (2017). Regjioni Lindor $i$ Kosovës - Veçoritë fiziko-gjeografike, resurset natyrore dhe problemet gjeomjedisore. Prishtina: ASHAK.

Doygun, H. (2009). Effects of urban sprawl on agricultural land: A case study of Kahramanmaraş, Turkey. Environmental Monitoring and Assessment, 158(1-4), 471-478. https://doi.org/10.1007/s10661-0080597-7

Gilbert, O. L. (1989). The ecology of urban habitats. London: Chapman \& Hall.

Hardoy, J., Mitlin, D., Satterthwaite, D., \& Hardy, E. (2001). Environmental Problems in an Urbanizing World. Land Use Policy. https://doi.org/10.1016/S02648377(02)00010-8

Islami, H. (1985). The villages of Kosovo, A contribution for sociologicademographical study in rural evolution. Prishtina: RILINDJA.

Kim, D.-S., Kobayashi, S., \& Mizuno, K. (2003). Analysis of urbanization characteristics causing farmland loss in a rapid growth area using GIS and RS. Paddy and Water Environment, 1(4), 189-199. https://doi.org/10.1007/s10333-0030032-1 
Kosovo Census Data 2011. (2011).

Prishtina. Retrieved from

http://ask.rks-

gov.net/media/2009/kosovo-censusatlas-2011.pdf

Marcotullio, P. J., Braimoh, A. K., \& Onishi, T. (2008). The impact of urbanization on soils. In Land Use and Soil Resources. https://doi.org/10.1007/978-1-40206778-5_10

Millennium Ecosystem Assessment. (2005). Urban Systems. Ecosystems and Human Well-Being: Current State and Trends. https://doi.org/10.2307/134206

Mount, J. F. (1995). California Rivers and Streams. University of California Press.

Ramadani, I. (2004). Rural development: organization and spatial regulation of rural settlements in region. Pejë: DUKAGJINI.

Ramadani, I., Bulliqi, S., Isufi, F., Gashi, G., Ejupi, A., \& Bytyqi, V. (2011). Extension of urban infrastructure in the village of Kosovo. In Procedia Social and Behavioral Sciences. https://doi.org/10.1016/j.sbspro.2011. 05.137

Richter, D. D. B. (2007). Humanity's transformation of earth's soil: Pedology's new frontier. Soil Science.

https://doi.org/10.1097/ss.0b013e318 $1586 \mathrm{bb} 7$

United Nations. (2001). Analysis of urban and rural population growth at the regional level. In World Urbanization Prospects: the 2001 Revision. 